\title{
SIMULATION PROGRAMS IN DISTANCE LEARNING
}

\author{
Ptak Pawel \\ Department of Automatic Control, Electrical Engineering and Optoelectronics \\ Czestochowa University of Technology, Poland
}

\begin{abstract}
In the era of the development of computer technology, methods were created that enable teaching, not only through direct contact with the student, but also through the computer network and the Internet. In order for this to be possible, programs allowing this type of activity had to be created. They are to model the operating conditions of electronic and measurement systems in virtual space as much as possible. Such programs must reflect the operation of such systems under operating conditions, taking into account disturbing signals. They should also be adapted to remote work via the Internet. In the era of epidemics, when the possibilities of teaching in the classical form are very limited or impossible, simulation programs working in a network environment may make sense. The results of modeling the operation of systems in virtual reality and the created measurement systems can be sent electronically. This allows their verification with the laboratory teacher and joint work on the project by a group of students during the laboratory classes.
\end{abstract}

Keywords: electronic and measuring systems, remote work, simulation programs.

\section{Introduction}

Along with the development of computer technology and PC software, applications have been created that allow modeling the operating conditions of electronic and measuring systems in the virtual space (Noga, Olszewska, Ptak, Prauzner, \& Migo, 2018). Programs of this type must reflect the operation of this type of systems under operating conditions, taking into account disturbing signals (Prauzner et al., 2020). This task is very well fulfilled by integrated software environments such as LTSpice or Multisim by National Instruments (Olszewska, Prauzner, Krupa, \& Ptak, 2018).

Integrated software environments are specialized software packages that have a variety of built-in functions to achieve a specific goal (Prauzner \& Ptak, 2018). For programming environments it will be a utility application, and for measurement environments it will be, for example, an application controlling the operation of a measurement system (Ptak \& Prauzner, 2017). Designing a measurement system consists in creating connections and dependencies between objects presented in graphic form. These objects are placed on virtual desktops using the drag-and-drop technique (Swisulski, 2004). Performing an operation on a specific object (e.g. clicking the mouse) creates the so-called events. The 
user's task is to create a set of handling events of this type (Ptak, Prauzner, Noga, Migo, \& Depešova, 2020). This is done with the use of programming languages such as C or Basic, or with the help of graphic languages (Winiecki, 2001). The aim of the research was to check the capabilities of the software for remote work with electronic systems. To achieve this, the capabilities of the two described programs were compared, using them to perform the same design tasks. The main features of selected integrated development environments are described below.

\section{Integrated Software Packages}

The LTSpice software suite is a free application from Linear Technology Corporation ${ }^{\circledR}$. It is designed to design electronic circuits and simulate their operation in a software environment. The construction of the electronic circuit in the program consists in selecting the appropriate symbols describing electronic elements from the program menu and inserting them into the virtual simulation screen. These elements on the simulation screen should be connected with each other according to the schematic diagram of the electronic system (Ptak, 2018b). The program is equipped with an extensive library of electronic elements and components. This makes it possible to build not only simple but also quite complex electronic circuits. The database of elements used for simulation can be extended by installing libraries from the software manufacturer's website.

Thanks to the extensive functions of the LTSpice software package, the operation of the designed electronic circuits can be analyzed using built-in measuring and recording devices. The current and voltage values can be checked at selected points of the tested electronic circuit. An example of a system built in LTSpice is shown in Figure 1.

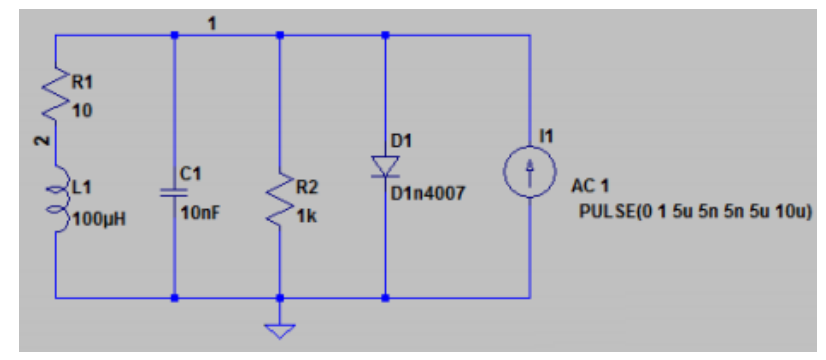

Figure 1 Sample Electronic Circuit Built in LTSpice (Pilarek, 2020)

The software package of National Instruments Corporation ${ }^{\circledR}$ - Multisim Education enables the construction and simulation of electric and electronic circuits, and is also used for computer analysis of analog and digital circuits (Prauzner, 2016). In this program, we can perform graphical editing of 
electronic diagrams. It has a built-in library of models of electronic components, both digital and analog. This enables the construction of a large number of not only simple but also more advanced measurement and research systems. The elements that are used to build these systems have been divided into groups in terms of their functions (Ptak, 2018a). Among them, we can distinguish the following functional groups: operational amplifiers, power sources, transistors, diodes, TTL elements, passive elements, CMOS elements, analog integrated circuits, digital integrated circuits, mechanical elements, displays and indicators, and elements of radio technology.

The electronic components built into the software package are available in two versions: real and virtual. The parameters of virtual elements can be changed before the simulation as well as during its duration. Properties of real elements are typical of electronic elements available on the market, and their parameters cannot be changed. Different types of elements have different colors as well as the associated data flow paths. In simulated electronic circuits, real and ideal elements can be used simultaneously (Ptak \& Prauzner, 2019). The measuring instruments built into the system are also available in two types: simulated and real. The latter is a representation of real measuring instruments with a realistic appearance of the faceplate, regulation and control elements. These elements look the same as in a real measuring instrument.

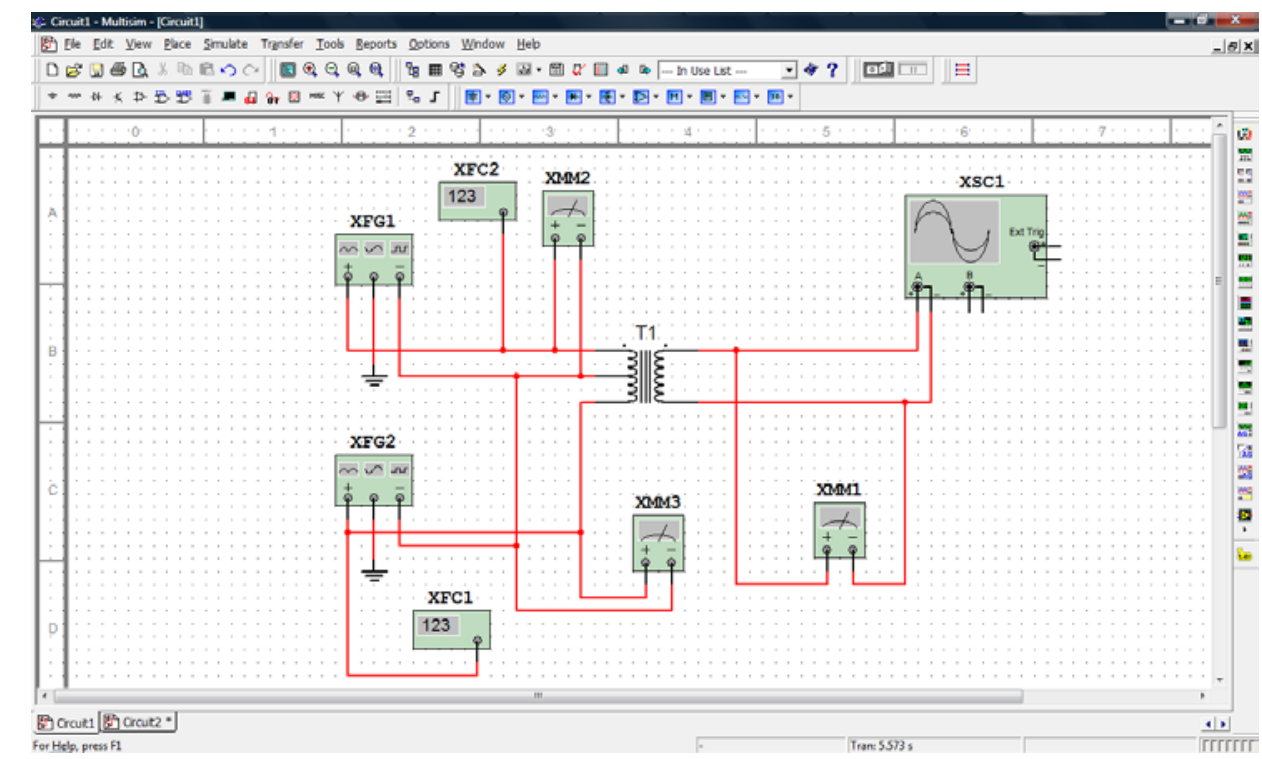

Figure 2 An Example of an Electronic Circuit Built in the Multisim Education Program (Ptak, 2011)

The Multisim Education software package allows you to perform interactive simulations of constructed electronic systems. The designed electronic circuits can be analyzed in terms of their operation. For this purpose, 
the output signals are tested and the operation of the simulated system is checked. By analyzing the operation of electronic systems, it is possible to adjust the parameters of the generated measurement and supply signals and check how these changes affect the operation of the simulated systems. Analysis of the operation of electronic circuits is also possible thanks to measuring and recording devices. The measured signals can be observed on the screen of the oscilloscope built into the system and saved as graphic files. During the analysis of the work of the designed electronic systems, its operating parameters can be changed and the results of these changes can be observed. It is similar to working in a real electronics laboratory where we use real measuring equipment. The Multisim Education software package is more extensive and has more possibilities than the LTSpice software package for similar tasks. Figure 2 shows exemplary results of the simulation of the operation of the electronic system built in the Multisim Education software package.

\section{Sample Simulations}

To check the capabilities of the integrated LTSpice and Multisim Education software packages, simulations of two measuring systems were performed. The first circuit is a derivative circuit built using an operational amplifier. Figure 3 shows a diagram of the tested differentiating system designed in the Multisim Education program.

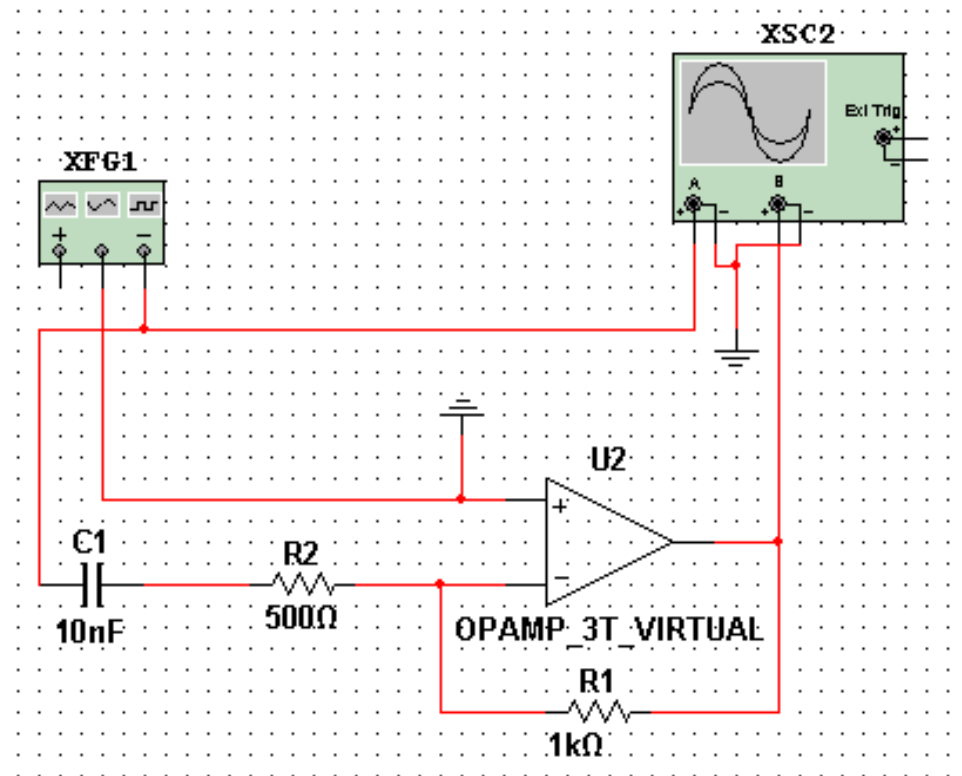

Figure 3 Diagram of the Differential Circuit Built in the Multisim Education Program (Pilarek, 2020) 
Figure 4 shows a schematic of a differentiator built in the LTSpice software package.

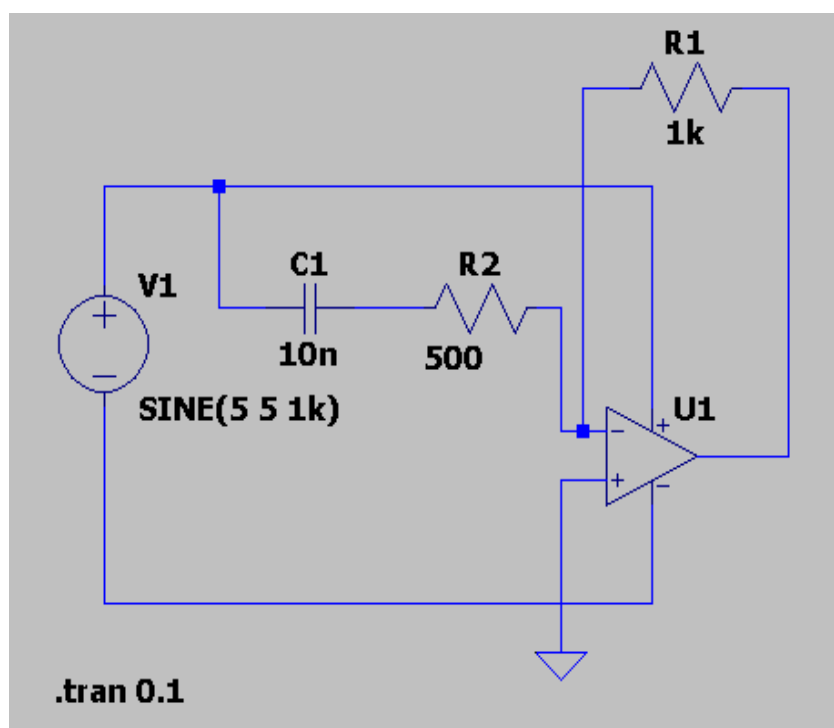

Figure 4 Scheme of the Differential Circuit Built in LTSpice (Pilarek, 2020)

The test was carried out for a square wave input with a signal amplitude of $5 \mathrm{~V}$ and a frequency of $1 \mathrm{kHz}$. After conducting the simulation, it was necessary to check whether the shape of the obtained waveform was consistent with the theoretical assumptions. The control of the output voltage also made it possible to check the correct operation of the differentiator.

Figure 5 shows the results of the simulation of the tested system in the Multisim Education program. The characteristic shows the voltage at the output of the tested system.

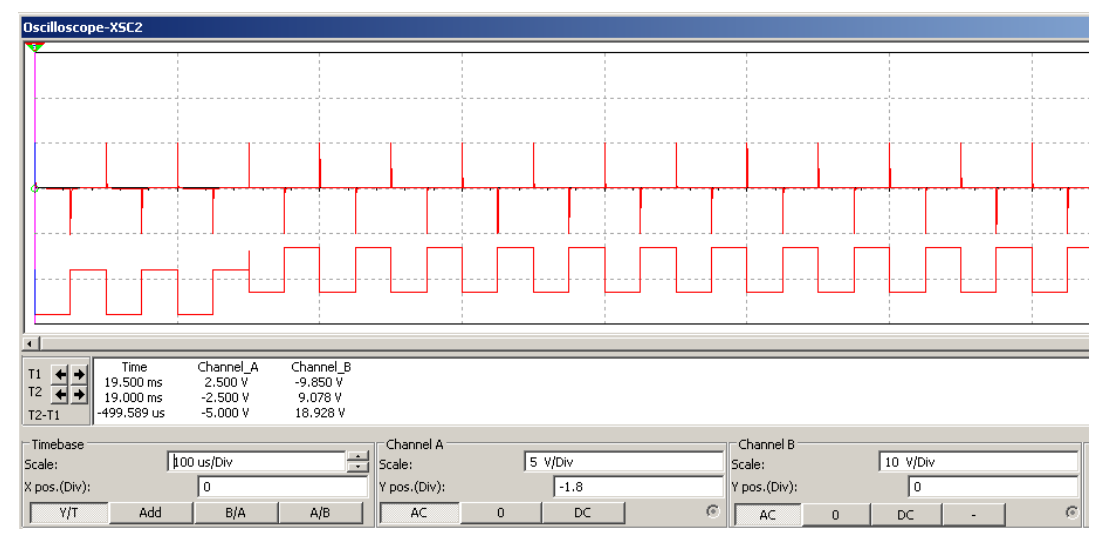

Figure 5 Voltage Value at the Output of the Tested System in the Multisim Education Program (Pilarek, 2020) 
Figure 6 shows the results of the simulation performed in the LTSpice software package.

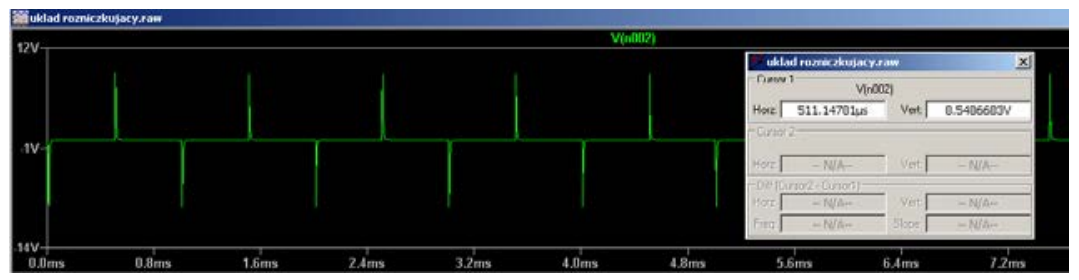

Figure 6 Characteristics of the Output Voltage of the Simulated Circuit in the LTSpice Program (Pilarek, 2020)

Based on the simulation results in LTSpice and Multisim Education, it can be concluded that the results obtained in the simulations are comparable. The shapes and values of the signals are similar to the values obtained from theoretical calculations.

The second simulation that was performed was the construction of an inverting operational amplifier based on the LM741 electronic circuit. The aim of the test was to measure the maximum value of the voltage at the output of the system. The test was performed for several gain values: $\mathrm{k}=1 ; 10$; 50 ; and 100 . Figure 7 shows a schematic diagram of an operational amplifier built in the Multisim Education program.

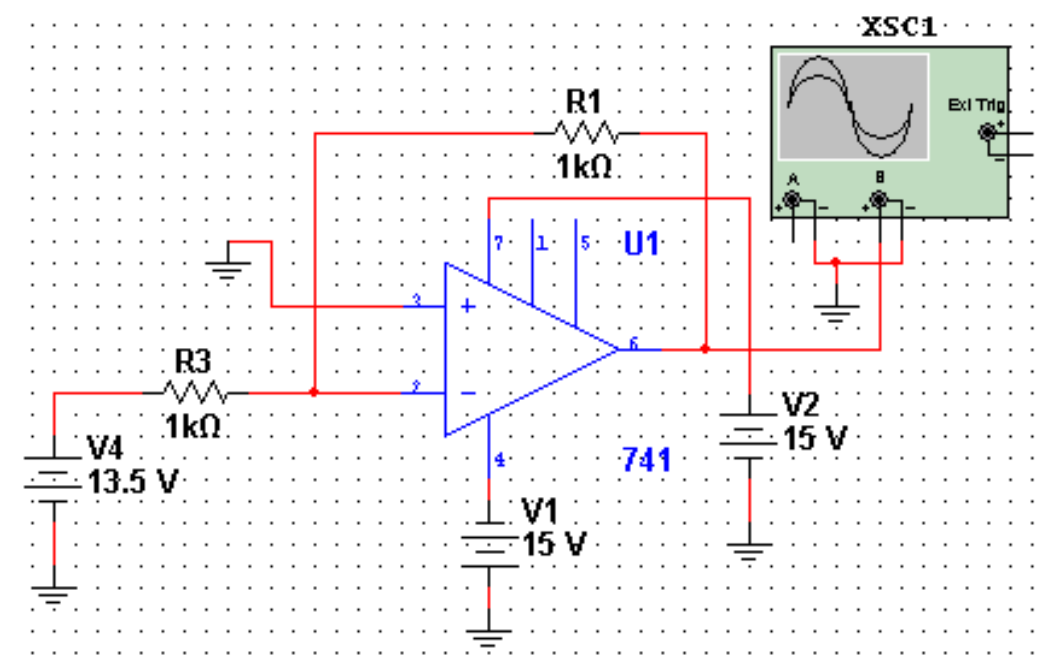

Figure 7 Diagram of an Operational Amplifier Built in the Multisim Education Program (Pilarek, 2020)

The same electronic circuit is designed in the LTSpice software package. The system was made to compare the simulation properties in both programs. Figure 8 shows a schematic diagram of an inverting op amp built in LTSpice. 


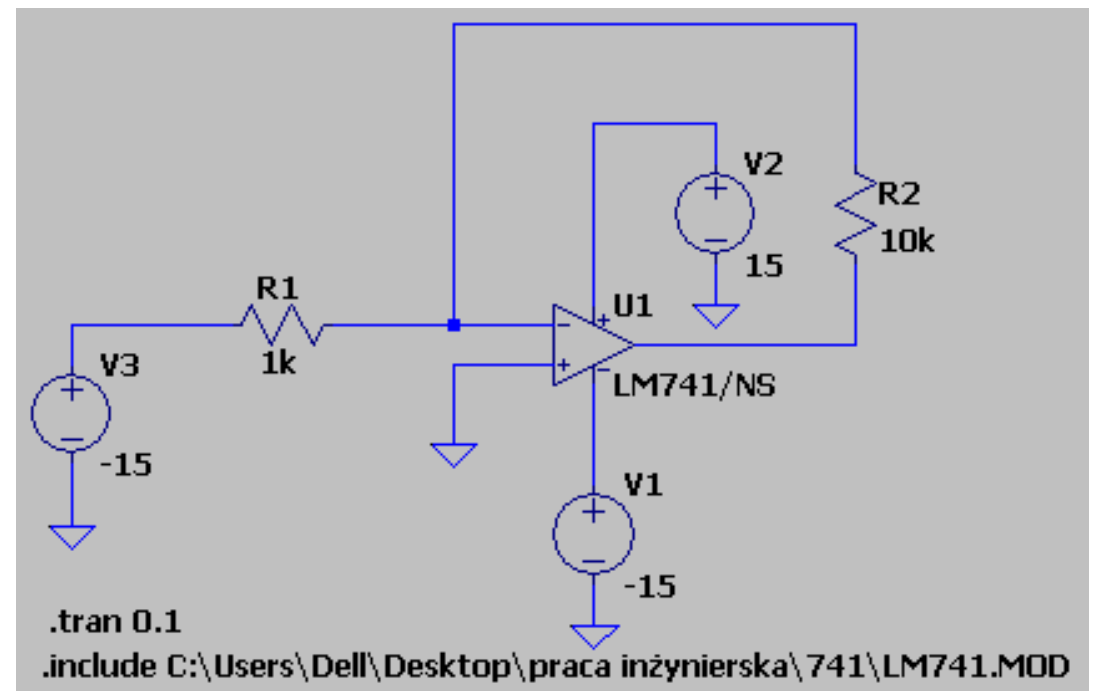

Figure 8 Diagram of an Operational Amplifier Built in LTSpice (Pilarek, 2020)

After the simulation, the characteristics of the dependence of the output voltage on the input voltage were made. The measurements were made for the amplification of the amplifier with the value $\mathrm{k}=1$. For comparison, the characteristics of the amplifier determined on the basis of actual measurements are additionally presented. The performed characteristics were used to present in one graph together with the characteristics obtained on the basis of simulations in LTSpice and Multisim Education programs. The obtained results of the programs' work are shown in Figure 9 in the form of the dependence of the output voltage on the input voltage.

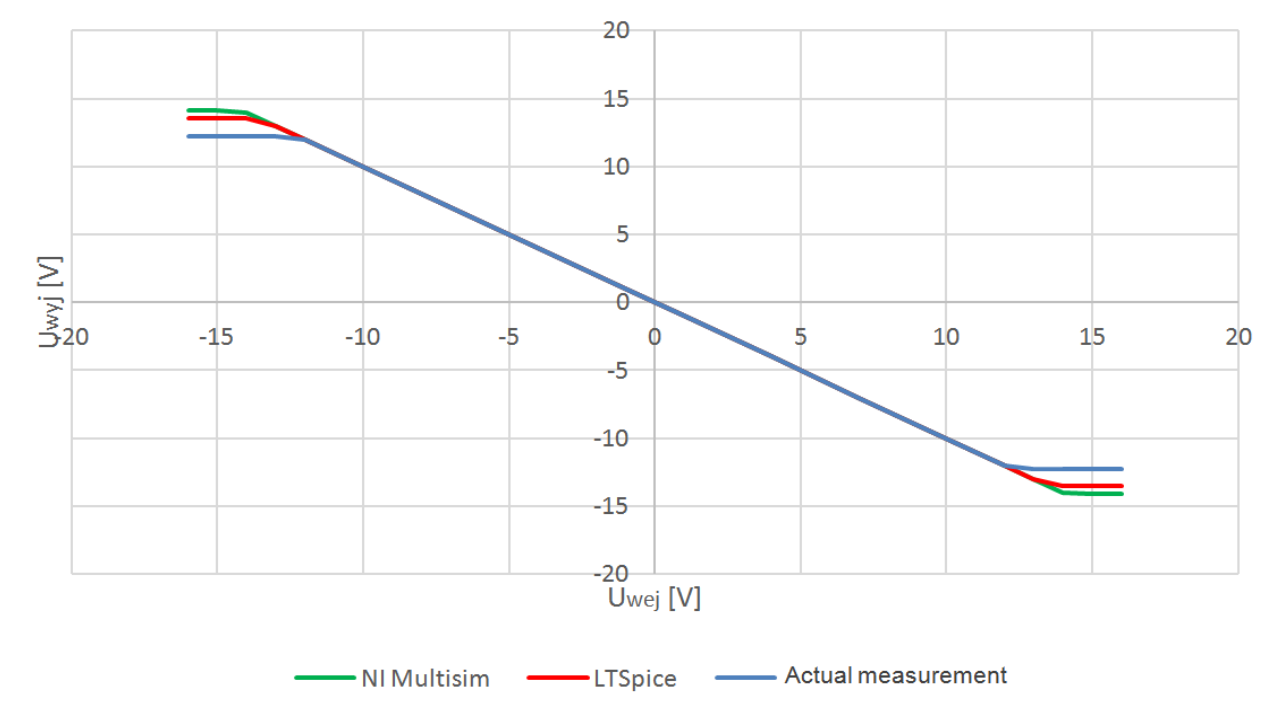

Figure 9 The Operational Amplifier Output Voltage Distribution Characteristics Obtained on the basis of Simulations (Pilarek, 2020) 
The data obtained as a result of simulations in the LTSpice and Multisim Education software packages are very similar. As shown in the figure, the values of the output voltage of the operational amplifier in the simulations have a similar value and almost the same characteristics as the values obtained as a result of empirical measurements. LTSpice turned out to be minimally more accurate, but it is not a significant difference. Both programs can be used without problems as virtual laboratories for researching and designing analog and digital electronic circuits.

\section{Program Packages in Distance Learning}

From the beginning of the development of computer technology and the Internet, a new possibility of distance learning has appeared. First, it was an innovative method that appeared as a curiosity. It was usually used in desolate places in the wilderness where, due to the small population, there are not many schools for children and teenagers. Successfully used in countries such as Australia or the United States in Alaska. Later, with the advancement of computer technology, distance learning became a complement to the traditional teaching method in a traditional school. Along with gaining experience, a lot of specialized software was developed, e.g. moodle type for such applications. Unfortunately, distance learning has not yet become dominant in the education process. It was slowly gaining the trust of teachers all over the world who had more and more experience with this software.

It is only recently that the worldwide epidemic of the covid-19 coronavirus has caused many schools in the world to quickly switch to long-distance work. The experience gained in previous years has now been of great use. Remote teaching procedures needed to be developed quickly. In Poland, the Moodle and Microsoft Teams platforms are the most popular. These platforms cover the entire course of the education process, regardless of the field they concern. It became necessary to supplement these platforms with specialized software packages.

In the field of electronics and electrical engineering, these packages are intended to support the education process. This especially applies to classes conducted in laboratories where we have access to electronic and measuring equipment (Prauzner, 2015a). Due to the epidemic, schools and universities have often switched to remote work. This resulted in the lack of access of pupils and students to electronic equipment and measuring systems in laboratories. Integrated software packages such as LTSpice or Multisim Education turned out to be a solution to this problem. As has been checked in the chapter "Sample simulations", we can use them as a replacement for work in a stationary laboratory at school or university. The results obtained during the simulation are 
very similar to the results obtained in the simulation programs (Prauzner, 2020). The choice of a specific program is due to several factors. It can be a financial matter because LTSpice is free and the price of Multisim Education is high. Our choice may also result from the possibilities that individual programs have. It can also be the result of a user's habituation to certain software (Prauzner 2017). If other people with whom we perform laboratory exercises have a specific program, this may be a decisive criterion for the selection. With the same software, you can work together on common tasks in electronics or electrical engineering.

The programs do not allow you to work on a project simultaneously on the Internet. However, part of the work on the electronics can be done and the project sent to the next person for completion (Prauzner, 2015b). You can also make your own corrections and send it to someone else to test the layout and accept the changes (Prauzner, T., Prauzner, M., Prauzner, K., \& Ptak, 2019). Thanks to this, remote work becomes easier, although it is not possible to work on a project simultaneously by different people using their own copy of the same software on a PC.

As for the possibilities of the programs, they are quite large. You can design, build and test the operation of electronic circuits similar to working in a stationary laboratory (Prauzner, 2018). The advantage of this type of software package is that the individual stages of project work can be carried out safely at home. You don't have to expose yourself to contact with other people and you can still work together on a virtual task. In the program, we perform activities related to the construction and operation of the electronic system. On the other hand, on the Moodle and Microsoft Teams e-learning platforms, you can meet in a virtual room and discuss the problem. Thus, the program packages perfectly complement e-learning platforms, creating a common virtual base for distance learning.

\section{Summary}

Based on the simulations, we can describe the following observations:

1. LTSpice or Multisim Education software packages are a very good tool for working with the design, manufacture and operation of electronic circuits. The results of these simulations are comparable with the results carried out in a classic stationary laboratory.

2. When working on electronic systems, we do not incur unnecessary costs resulting from any mistakes that we may make in a stationary laboratory. They can be the result of damage to electronics or measuring instruments. By using software packages, all errors can be corrected at the circuit design stage, and others can be eliminated when testing the work of the finished project. It does not generate any costs. We can make any corrections without any problems at any stage of the project. When working with electronic components in a stationary laboratory, 
some corrections will no longer be possible without changing the entire design and may generate additional costs.

3. The use of LTSpice or Multisim Education program packages enables the project to be carried out by pupils or students and sent for review. The person conducting the classes can check the correctness of the project without direct contact, which is of particular importance in the period of the covid-19 epidemic. If the project has any disadvantages, the lecturer may contact the authors of the work via videoconference. This can be done using the Moodle and Microsoft Teams elearning platforms. The submitted comments will be used for corrections to be made in the designed and constructed electronic system.

4. With the use of the Moodle and Microsoft Teams e-learning platforms, the entire process of designing, implementing and testing the designed electronic systems can also be carried out during the videoconference. During the online lecture, the lecturer can answer questions and make any changes to the project. There is also a possibility that during the videoconference, the pupils or students will together with the teacher build the same layout on their computer in the program package.

5. The use of such a common base for distance learning will increase the level of education and the results obtained will be comparable to the results achieved in day-to-day teaching. Mutual involvement while working online increases the interest in the conveyed content and encourages independent work and competition with others.

6. At the present stage of the epidemic, it would be difficult to assess the quality of such education. In the future, after the Covid-19 threat has ceased, full learning outcomes studies should be performed. It is also necessary to check how the students rate this type of education and whether it suits them better than traditional classroom teaching.

\section{References}

Noga, H., Olszewska, D., Ptak, P., Prauzner, T., Migo, P., (2018). Badanie i symulacja oddziaływania zmiennego pola elektromagnetycznego na rozwój mikroorganizmów (Investigation and simulation of the influence of an alternating electromagnetic field on the development of microorganisms). Przeglad Elektrotechniczny, $R$ 94, $\mathrm{Nr} 1 / 2018$, 73-76.

Olszewska, D., Prauzner, T., Krupa, P., Ptak, P., (2018). Use of modern information technology in microbiological laboratory, Society. Integration. Education. Proceedings of the International Scientific Conference. Volume V, May 25th-26 ${ }^{\text {th }}$. Rēzekne: Rēzeknes Augstskola, Latvia, 380-389.

Pilarek, K. (2020). Analiza możliwości $i$ zastosowania programów symulacyjnych wspomagajacych nauczanie elektroniki $i$ elektrotechniki (Analysis of the possibilities and application of simulation programs supporting teaching of electronics and electrical engineering). Politechnika Częstochowska.

Prauzner, T. (2015). Analysis of the results of the pedagogical research and EEG in the aspect of effective modern teaching aids in the technical education. Society. Integration. Education. Proceedings of the International Scientific Conference. Volume IV, May 22th-23th 2015. Rēzekne: Rēzeknes Augstskola, Latvia, 480-489. 
Prauzner, T. (2015). Finite Element Method in an analysis of selected parameters of an inductive sensor for protective coatings measurements, Przeglad Elektrotechniczny, R. 91 NR 12/2015, 205-208.

Prauzner, T. (2016). Interactive computer simulation as a response to contemporary problems of technical education, Society. Integration. Education. Proceedings of the International Scientific Conference. Volume II, May 27th - 28 ${ }^{\text {th }}$. Rēzekne: Rēzeknes Augstskola, Latvia, 579-588.

Prauzner, T. (2017). The effectiveness of school education - featured implications considerations. Society. Integration. Education, Proceedings of the International Scientific Conference., Volume III, May 26th-27th 2017, Rēzekne: Rēzeknes Augstskola, Latvia, 558-564.

Prauzner, T. (2018). Cognitive mechanisms in the didactics of technical vocational subjects in the light of research on bioelectrical brain activity. Society. Integration. Education. Proceedings of the International Scientific Conference. Volume I, May 25th-26 ${ }^{\text {th }}$. Rēzekne: Rēzeknes Augstskola, Latvia, 454-463.

Prauzner T., Ptak P., (2018). Modelowanie i symulacja działania czujnika indukcyjnego pola magnetycznego (Modeling and simulation of the operation of an inductive magnetic field sensor). Przeglad Elektrotechniczny, R 94, Nr 1/2018, 89-92.

Prauzner, T., Prauzner M., Prauzner K., Ptak P. (2019). Cognitive activity in the respect of qeeg research - presentation of laboratory tests. Society. Integration. Education. Proceedings of the International Scientific Conference. Volume V, May 24th-25th. Rēzekne: Rēzeknes Augstskola, Latvia, 469-478.

Prauzner, T., (2020). Innovativeness of didactic practice in the field of current pedagogical knowledge, Society. Integration. Education. Proceedings of the International Scientific Conference. Volume II, May 22th -23th, 2020. Rēzekne: Rēzeknes Augstskola, Latvia, 247-255.

Prauzner, T., Prauzner, K., Ptak, P., Noga, H., Migo, P., Depešová, J., (2020). Wpływ warunków otoczenia na dokładność badań elektroencefalograficznych QEEG (The influence of environmental conditions on the accuracy of QEEG electroencephalography). Przeglad Elektrotechniczny, R. 96, NR 4/2020, 86-89.

Ptak, P. (2011). Metodyka analizy sygnałów w pomiarach grubości warstw wierzchnich (Methodology of signal analysis in measuring the thickness of surface layers). Ślaskie Wiadomości Elektryczne R.18 nr 4 (97), 44-46.

Ptak P., Prauzner T., (2017). Wykorzystanie sygnałów złożonych w badaniach zabezpieczenia antykorozyjnego elementów metalowych (The use of complex signals in tests of corrosion protection of metal elements). Przeglad Elektrotechniczny, 12/2017, 151-154.

Ptak, P., (2018). Application of multisim and ltspice software packages to simulate the operation of electronic components as an alternative to measurements of real elements, Society, Integration, Education. Proceedings of the International Scientific Conference. Volume V, May 25th-26th, 2018. Rēzekne: Rēzeknes Augstskola, Latvia, 409-419.

Ptak, P., (2018). Application of the software package ltspice for designing and analysing the operation of electronic systems, Society, Integration, Education. Proceedings of the International Scientific Conference. Volume V, May 25th-26th, 2018. Rèzekne: Rēzeknes Augstskola, Latvia, 402-408.

Ptak, P., Prauzner, T. (2019). The use of modern information technology in teaching electronics. Society. Integration. Education. Proceedings of the International Scientific Conference. Volume V, May 24th-25th. Rēzekne: Rēzeknes Augstskola, Latvia, 479-487. 
Ptak, P., Prauzner, T., Noga, H., Migo, P., Depešova, J., (2020). Wykorzystanie pola magnetycznego do badania stanu powłok ochronnych, (The use of a magnetic field to study the condition of protective coatings). Przeglad Elektrotechniczny, R. 96, NR 2/2020, 114-116.

Swisulski, D., (2004). Systemy pomiarowe, (Measurement systems). Gdańsk: Wydawnictwo Politechniki Gdańskiej.

Winiecki, W., (2001). Graficzne zintegrowane środowiska programowe, (Graphical integrated software environments). Warszawa: Wydawnictwo Mikom. 